\title{
(⿹

\section{Bør man justere for bakgrunnsvariabler i en randomisert studie?}

MEDISIN OG TALL

\section{STIAN LYDERSEN}

E-post: stian.lydersen@ntnu.no

Stian Lydersen er dr.ing. og professor i medisinsk statistikk ved Regionalt kunnskapssenter for barn og unge - psykisk helse og barnevern (RKBU Midt-Norge) ved Institutt for psykisk helse, NTNU. Forfatteren har fylt ut ICMJE-skjemaet og oppgir ingen interessekonflikter.

I en randomisert kontrollert studie skal det ikke være systematiske forskjeller i bakgrunnsvariabler mellom behandlingsgruppene. Enkelte ganger kan det likevel være fornuftig å justere for noen forhåndsdefinerte variabler i de statistiske analysene.

Noen ganger har man bakgrunnsvariabler som kan være sterke prediktorer for utfallsvariabelen. I en observasjonell studie er variabler ofte skjevfordelt mellom gruppene, og de kan da opptre som konfundere og medføre forventningsskjevhet (bias) i estimert effekt hvis man ikke justerer for dem. I en randomisert kontrollert studie vil det ikke være noen systematisk skjevfordeling. Men man kan øke statistisk styrke - og dermed presisjonen i effektestimatet - ved å justere for slike variabler (1, s. 417). Effekt på statistisk styrke er studert i (2) og (3), der man justerte for inntil fire prognostiske variabler samt tre variabler som ikke hadde effekt og var "støy». Statistisk styrke kunne økes vesentlig ved å inkludere sterke prognostiske variabler, og styrken ble lite redusert ved å inkludere variabler som var «støy».

\section{$\varnothing \mathrm{kt}$ presisjon}

I en randomisert kontrollert studie sammenliknet vi to behandlingsforl $ø$ p for pasienter med hoftebrudd $(4,5)$. Den primære utfallsvariabelen var mobilitet, målt med screeningtesten «Short Physical Performance Battery» (SPPB). Dette er en skalavariabel som går fra o til 12, og en differanse på over o,5 regnes som klinisk relevant (4). Pasientens alder, kjønn og type brudd var forhåndsvurdert som mulige prediktorer for mobilitet, og det ble justert for disse. Vi fant en klinisk relevant og statistisk signifikant effekt fire måneder etter operasjon (figur 1).Vi ser av figuren at den justerte analysen ga praktisk talt samme estimat som den ujusterte, men med smalere konfidensintervall og lavere p-verdi, noe som vanligvis vil være tilfelle. I logistisk regresjon kan det også være aktuelt å justere for slike prediktorer, men da blir estimatet vanskeligere å tolke (1, s. 417). 


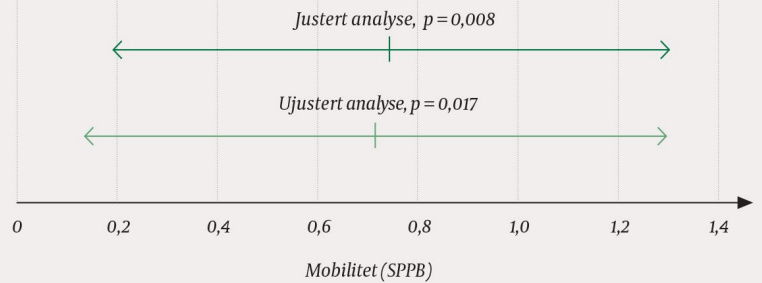

Figur 1 Sammenlikning av to behandlingsforløp for hoftebruddspasienter (4). Effekt på mobilitet målt med "Short Physical Performance Battery» (SPPB) fire måneder etter operasjon, fra en linecer blandet effekt-modell (mixed model). Estimat, $95 \%$ konfidensintervall og $p$-verdi fra justert analyse som er rapportert $i$ (4), og fra ujustert analyse av de samme dataene.

Det er helt avgjørende at man forhåndsdefinerer hvilke variabler man vil justere for, for å unngå fisking etter de bakgrunnsvariablene som gir lavest p-verdi. Alle de tre forhåndsdefinerte bakgrunnsvariablene ble beholdt i analysen (4), selv om kjønn viste seg å ikke ha noen betydning (data ikke vist).

Et annet eksempel er kovariansanalyse i en randomisert kontrollert studie der man måler en verdi både før behandling og ved oppfølging (6). Utgangsverdien av utfallsvariabelen er vanligvis en meget sterk prediktor og kan øke presisjonen i effektestimatet.

\section{Stratifisering og multisenterstudier}

Hvis randomiseringen blir gjort separat innenfor kategorier av bakgrunnsvariabler, for eksempel alder eller kjønn, kalles det stratifisert randomisering. En korrekt analyse bør ta hensyn til disse stratifiseringsvariablene ved å justere for dem i analysen (7).

Noen studier inkluderer pasienter fra flere sentre, for eksempel flere klinikker. Pasienter ved samme klinikk kan ofte være mer lik hverandre enn pasienter ved forskjellige klinikker. Dette bør man ta hensyn til i analysen.

\section{Konklusjon}

Det kan enkelte ganger være fornuftig å justere for bakgrunnsvariabler i en randomisert kontrollert studie. Men disse variablene må være spesifisert før man gjør analyser.

\section{LITTERATUR:}

1. Vittinghoff E, Glidden DV, Shiboski SC et al. Regression methods in biostatistics linear, logistic, survival, and repeated measures models. 2nd utg. New York: Springer, 2012.

2. Kahan BC, Jairath V, Doré CJ et al. The risks and rewards of covariate adjustment in randomized trials: an assessment of 12 outcomes from 8 studies. Trials 2014; 15: 139. [PubMed][CrossRef]

3. Thompson DD, Lingsma HF, Whiteley WN et al. Covariate adjustment had similar benefits in small and large randomized controlled trials. J Clin Epidemiol 2015; 68: 1068-75. [PubMed][CrossRef]

4. Prestmo A, Hagen G, Sletvold O et al. Comprehensive geriatric care for patients with hip fractures: a prospective, randomised, controlled trial. Lancet 2015; 385: 1623-33. [PubMed][CrossRef]

5. Lydersen S. Unngå signifikanstesting av bakgrunnsvariabler i randomiserte studier. Tidsskr Nor Legeforen 2020; 140. doi: 10.4045/tidsskr.19.0684. [CrossRef]

6. Vickers AJ, Altman DG. Statistics notes: Analysing controlled trials with baseline and follow up measurements. BMJ 2001;323: 1123-4.

7. Kahan BC, Morris TP. Reporting and analysis of trials using stratified randomisation in leading medical journals: review and reanalysis. BMJ 2012;323: e5840. [PubMed][CrossRef] 
Publisert: 26. mars 2020. Tidsskr Nor Legeforen. DOI:10.4045/tidsskr.19.0685

(C) Tidsskrift for Den norske legeforening 2020. Lastet ned fra tidsskriftet.no 